\title{
PENGARUH PENAMBAHAN EKSTRAK DAUN KEMANGI (Ocimum basilicum L.) TERHADAP AKTIVITAS ANTIBAKTERI BASIS PASTA GIGI
}

\author{
Dewi Nurmashita, Laode Rijai, Riski Sulistiarini \\ Laboratorium Penelitian dan Pengembangan FARMAKA TROPIS, Fakultas Farmasi, \\ Universitas Mulawarman, Samarinda, Kalimantan Timur \\ Email: mashita.farmasi011@gmail.com
}

\begin{abstract}
Preventation of dental and oral health problems is very important. Brushing teeth is an effective method for solve this issue. The addition of herbal ingredients in toothpaste is expected to prevent oral health problems because it has the ability to inhibit the growth of microbes. Basil leaves (Ocimum basilicum L.) has good antibacterial activity. The aims of study to determine the effect of antibacterial activity toothpaste base by adding basil leaf extract in inhibiting the growth of microbes. Basil leaves extracted using $96 \%$ ethanol. Antibacterial activity of basil leaf extract were tested on Streptococcus mutans by using variations of concentration of $25,50,100,150$, and $200 \mathrm{mg} / \mathrm{mL}$. Toothpaste base made by varying concentrations of calcium carbonate (abrasive) $37 \%$ (F1), $42 \%$ (F2) and 47\% (F3). Toothpaste base that has been created is added with variations of concentration basil leaf extract are 25,50 and $100 \mathrm{mg} / \mathrm{mL}$ in each formula. Antibacterial activity of formulas were tested on Streptococcus mutans. The results showed that best inhibition zone diameter of the extract at concentration of $15 \mathrm{mg} / \mathrm{mL}(6,247 \mathrm{~mm})$, and the best inhibition zone diameter of toothpaste basis is F1 $(11.386 \mathrm{~mm})$. Beside it, the toothpaste preparation (F1) had the inhibition zone diameter is $4.103 \mathrm{~mm}$.
\end{abstract}

Key words: Ocimum basilicum L., toothpaste, antibacterial, Sterptococcus mutans

\begin{abstract}
ABSTRAK
Pencegahan terjadinya masalah kesehatan gigi dan mulut sangat diperlukan. Menyikat gigi merupakan metode yang efektif untuk menanggulangi masalah tersebut. Penambahan herbal pada pasta gigi diharapkan dapat mencegah terjadinya masalah kesehatan gigi dan mulut karena memiliki kemampuan menghambat pertumbuhanmikroba. Daun kemangi (Ocimum basilicum L.) memiliki aktivitas antibakteri yang baik. Penelitian ini bertujuan untuk mengetahui pengaruh aktivitas antibakteri basis pasta gigi dengan penambahan ekstrak daun kemangi dalam menghambat pertumbuhan mikroba. Daun kemangi diekstraksi dengan menggunakan etanol 96\%. Ekstrak daun kemangi diuji antibakterinya terhadap bakteri Sterptococcus mutans dengan menggunakan variasi konsentrasi yaitu 25, $50,100,150$, dan $200 \mathrm{mg} / \mathrm{mL}$. Basis pasta gigi dibuat dengan memvariasikan konsentrasi kalsium karbonat (abrasif) 37\% (F1), 42\% (F2) dan 47\% (F3). Basis pasta gigi yang telah dibuat ditambahkan dengan variasi konsentrasi ekstraiuk daun kemangi yaitu 25, 50 dan $100 \mathrm{mg} / \mathrm{mL}$ pada setiap formula. Semua formula diuji aktivitas antibakterinya terhadap bakeri Streptococcus mutans. Hasil penelitian menunjukkan diameter zona bening paling baik pada ekstrak adalah pada konsentrasi $15 \mathrm{mg} / \mathrm{mL}(6,247 \mathrm{~mm})$, pada basis pasta gigi
\end{abstract}


adalah formula 1 (F1) (11,386 mm).Dan pada sediaan pasta gigi adalah pada formula 1 (F1) dengan zona penghambatan sebesar 4,103 $\mathrm{mm}$.

Kata kunci: Ocimum basilicum L., pasta gigi, antibakteri, Streptococcus mutans

\section{PENDAHULUAN}

Rongga mulut merupakan salah satu tempat dalam tubuh yang mengandung mikroorganisme dengan populasi dan keanekaragaman paling tinggi dibanding tempat lain. Kebersihan rongga mulut dapat dilihat dari ada tidaknya deposit-deposit organik, seperti pelikel, materi alba, sisa makanan, kalkulus, dan plak gigi [1]. Indonesia merupakannegara yang berkembang, masyarakat umumnya membiasakan menyikat gigi secara manual dengan pasta gigi sebagai hal yang umum dan secara potensial efektif terhadapkebersihan rongga mulut [1].

Angka kejadian masalah

kesehatan gigi dan mulut di Indonesia tergolong tinggi. Berdasarkan Riset Kesehatan Dasar (Riskesdas) Nasional Tahun 2007, prevalensi nasional masalah gigi-mulut adalah $23,4 \%$. Terdapat $1,6 \%$ penduduk yang telah kehilangan seluruh gigi aslinya. Penduduk yang menerima perawatan atau pengobatan dari tenaga kesehatan gigi hanya $29,6 \%$ dari total penduduk dengan masalah gigi-mulut [3].

Upaya pencegahan terhadap masalah tersebut dapat dilakukan secara mekanis maupun secara kimiawi. Pencegahan secara mekanis meliputi penyikatan gigi dan pengunaan benang gigi. Saat ini pasta gigi yang beredar dipasaran dilengkapi dengan penambahan jenis bahan aktif yang mengandung bahan alami ataupun sintetik sebagai bahan antimikroba. Bahan antimikroba tersebut tersedia dalam bentuk larutan kumur dan pasta gigi. Penelitian sebelumnya menunjukkan pembersihan gigi dengan menyikat gigi menggunakan pasta gigi lebih efektif dibandingkan dengan menyikat gigi tanpa pasta gigi
[4]. Pasta gigi yang digunakan pada saat menyikat gigi berfungsi untuk mengurangi pembentukan plak, memperkuat gigi terhadap karies, membersihkan dan memoles permukaan gigi, menghilangkan atau mengurangi bau mulut, memberikan rasa segar pada mulut serta memelihara kesehatan gusi [5]. Pasta gigi pada umumnya mengandung bahan abrasif, air, pelembab, bahan perekat, bahan penambah rasa, bahan terapeutik, bahan desensitisasi, bahan anti-tartar, bahan pemutih, bahan pengawet, serta bahan antimikroba seperti triklosan dan klorheksidin yang berperan sebagai bahan aktif yang dapat memberikan efek inhibisi secara langsung pada pembentukan plak [4].

Penelitian Rizki dkk [4] melaporkan bahwa pasta gigi herbal lebih efektif dibandingan pasta gigi non-herbal dalam menurunkan indeks plak. Penambahan herbal pada pasta gigi dapat menghambat pertumbuhan plak, karena beberapa jenis herbal memliki kemampuan menghambat pertumbuhan mikroba. Bahan antimikroba pada ekstrak daun sirih dan siwak berperan sebagai bahan aktif dan mampu membunuh bakteri yang menjadi penyebab terbentuknya plak. Selain itu, karena herbal berasal dari tumbuh-tumbuhan, maka bahan tersebut aman dan alami.

Daun Kemangi (Ocimum basilicum L.) merupakan salah satu tanaman lainnya yang memiliki potensi sebagai antibakteri. Kandungan di dalam daun kemangi bahwa senyawa metabolit yang terkandung di dalamnya adalah flavonoid, tanin, steroid dan saponin [6]. Daun kemangi juga telah dikembangkan dalam bentuk sediaan mouthwash (obat kumur) untuk menjaga kebersihan dan kesehatan daerah rongga mulut [7]. 


\begin{abstract}
Berdasarkan uraian tersebut dilakukan penelitian dengan memformulasi pasta gigi dengan penambahan ekstrak daun kemangi ( Ocimum basilicum L.) yang kemudian dilakukan pengujian aktivitas antibakteri dari sediaan yang telah dibuat.
\end{abstract}

\section{METODOLOGI}

\section{Bahan}

Sampel daun kemangi diambil dari Desa Bangun Rejo Kecamatan Tenggarong Sebrang Kota Tenggarong. Identfikasi tanaman dilakukan di Laboratorium Dendrologi Fakultas Kehutanan Universitas Mulawarman. Bakteri Streptococcus mutans diperoleh dari Laboratorium Biologi Farmasi Fakultas Farmasi Universitas Mulawarman. Media yang digunakan yaitu medium NA (Nutrient Agar). Etanol 95\%, $\mathrm{NaCl} 0,9 \%$, air suling, paper disk, gliserin, kalsium karbonat, natrium lauril sulfat, mentol, aerosil, Na$\mathrm{CMC}$, nipagin, dan natrium sakrin.

\section{Peralatan}

Peralatan yang digunakan dalam penelitian ini yaitu timbangan analitik, cawan porselin, botol vial, batang pengaduk, spoid, botol semprot, erlenmayer, rotary evaporator, Laminar Air Flow $(L A F)$, cawan petri, tabung reaksi, pembakar spiritus, pinset, inkubator, beaker glass, magnetic sterirrer,sterirrer,mortir, stemper, pot salep, jarum ose, dan autoclave.

\section{Prosedur}

\section{Preparasi ekstrak}

Daun kemangi diambil sebanyak 678,86 g dicuci hingga bersih dan dikeringanginkan. Setelah kering daun kemangi dimaserasi dengan menggunakan pelarut etanol $96 \%$ selama 3 x 24 jam dalam suhu kamar. Kemudian larutan etanol disaring hingga di peroleh filtrat. Filtrat pelarut tersebut kemudian diuapkan dengan menggunakan Rotary evaporator sehingga dihasilkan ekstrak kental daun kemangi.Ekstrak kemangi yang didapat dihitung rendemennya.

\section{Pembuatan Media}

Media nutrien agar (NA) sebanyak 5 gramdimasukkan kedalam erlenmeyer lalu dilarutkan dengan menambahkan $250 \mathrm{~mL}$ air suling, kemudian dipanaskan hingga mendidih di atas hot platesambil dihomogenkandan ditutup alumuniumfoil. Kemudian media disterilisasikan dengan autoklaf pada suhu $121^{\circ} \mathrm{C}$ selama 15 menit dan tekanan $2 \mathrm{~atm}$.

\section{Pemurnian Bakteri}

Biakan bakteri Streptococcus mutanssebanyak satu ose diinokulasikan kedalam medium agar miring NA yang telah membeku secara terpisah dan aseptis dengan meletakkan ose bulat yang mengandung biakan pada dasar kemiringan agar dan ditarik dengan gerakan zig-zag (metode streak). Selanjutnya diinkubasi dalam inkubator pada suhu $37^{\circ} \mathrm{C}$ selama 24 jam.

\section{Pembuatan Suspensi Kultur Murni Bakteri Uji}

Sebanyak $9 \mathrm{~mL} \mathrm{NaCl} 0,9 \%$ dimasukkan kedalam tabung reaksi yang berisi bakteri uji. Suspensi kultur bakteri uji kemudian dihomogenkan (1:10). Sebanyak $5 \mathrm{~mL}$ dari konsentrasi 1:10 diambil dan dimasukkan kedalam tabung reaksi yang berisi $5 \mathrm{~mL}$ Nacl $0,9 \%$ (1:20). Kemudian $5 \mathrm{~mL}$ dari 1:20 dimasukkan kedalam tabung reaksi yang berisi $5 \mathrm{~mL} \mathrm{NaCl} \mathrm{0,9 \%} \mathrm{(1:40).}$

\section{Pembuatan Konsentrasi Ekstrak Etanol Daun Kemangi}

Konsentrasi ekstrak etanol daun kemangi ditentukan berdasarkan uji pendahuluan yaitu2,5, 5, 10, 15 dan 20 $\mathrm{mg} / \mathrm{mL}$. Larutan sampel dibuat dengan 
cara menimbang ekstrak kental kemangi masing-masing $0,025 \mathrm{~g}, 0,05 \mathrm{~g}, 0,1 \mathrm{~g}$, $0,15 \mathrm{~g}$, dan $0,2 \mathrm{~g}$ kemudian tiap konsentrasi dilarutkan dengan aquades dan tween 80 untuk membantu kelarutannya hingga volumenya $1 \mathrm{ml}$. Kontrol negatif menggunakan campuran aquades dan tween 80 sebanyak $1 \mathrm{ml}$.

\section{Pengujian aktivitas antibakteri ekstrak} Uji aktifitas antibakteri dilakukan dengan metode difusi, menggunakan kertas saring Whatman berdiameter $5 \mathrm{~mm}$. Media NA yang telah dipanaskan sebanyak $10 \mathrm{ml}$ dimasukkan kedalam botol pengencer yang telah berisi suspensi bakteri 1:40. Larutan campuran yang telah homogen dituang kedalam cawan petri. Paper disk berdiameter $5 \mathrm{~mm}$ direndam dalam larutan ekstrak daun kemangi selama 15 menit, kemudian diletakkan pada permukaan media yang telah memadat. Media yang telah diisi sediaan uji kemudian diinkubasi pada suhu $37^{\circ} \mathrm{C}$, selanjutnya dilakukan pengamatan dan pengukuran zona bening yang terbentuk pada jam ke-24.

\section{Formulasi pasta gigi}

Tiga formula pasta gigi dengan variasi konsentrasi kalsium karbonat 37 ,
42, dan $47 \%$ sebagai abrasif (Tabel 1) yang mana masing-masing formula berisi ekstrak kemangi dengan konsentrasi 2,5 $\mathrm{mg}, 5 \mathrm{mg}$ dan $10 \mathrm{mg}$. Perhitungan jumlah ekstrak yang ditambahkan didapatkan berdasarkan perhitungan jumlah rata-rata individu dalam mengambil pasta gigi (Tabel 2).

Untuk membuat NaCMC dicampurkan dengan gliserin sampai benar-benar basah kemudianditambahkanair yang berisi natrium sakarin, diaduk sampai membentuk massa gel (Fase A). Ditempat terpisah, dilarutkan mentol dengan etanol dalam mortir sampai larut. Ditambahkan nipagin, Colloidal silica dioxide dankalsium karbonat sampai homogen (Fase B). Dicampur fase A kedalam fase $\mathrm{B}$ diaduk hingga membentuk massa pasta (Fase C). Ditambahkan natrium lauril sulfat kedalam fase $\mathrm{C}$, dilakukan pengadukan hingga homogen. Ekstrak kemangi sesuai dengan perhitungan ditambahkan kedalam pasta, dan diaduk hingga homogen. Pasta gigi yang telah dibuat kemudian diuji aktivitas antibakterinya. Pengujian aktivitas antibakteri dilakukan terhadap basis pasta gigi dan sediaan pasta gigi.

Tabel 1. Komposisi pasta gigi [8]

\begin{tabular}{llrrr}
\hline \multirow{2}{*}{ Bahan $(\%)$} & \multicolumn{2}{c}{ Fungsi } & \multicolumn{3}{c}{ Formula } \\
\cline { 3 - 5 } & & \multicolumn{2}{c}{ F1 } & \multicolumn{1}{c}{ F3 } \\
\hline Gliserin & Humektan & 28 & 28 & 28 \\
Natrium karboksil metilselulosa & Gelling agent & 0,5 & 0,5 & 0,5 \\
Air suling & Pelarut & 20.02 & 15,02 & 10,02 \\
Natrium sakarin & Pemanis & 0,5 & 0,5 & 0,5 \\
Nipagin & Pengawet & 0,18 & 0,18 & 0,18 \\
Kalsium karbonat & Abrasif & 37 & 42 & 47 \\
Aerosil & Gelling agent & 3,5 & 3,5 & 3,5 \\
Natrium lauril sulfat & Surfaktan & 2 & 2 & 2 \\
Mentol & Korigen odoris & 0,3 & 0,3 & 0,3 \\
\hline
\end{tabular}


Tabel 2. Jumlah individu dalam mengambil pasta gigi

\begin{tabular}{cc}
\hline Individu & Jumlah pasta gigi yang diambil $(\mathrm{gram})$ \\
\hline I & 1,3106 \\
II & 1,0693 \\
III & 2,1013 \\
IV & 1,1689 \\
V & 2,0002 \\
VI & 2,1780 \\
VII & 1,8919 \\
VIII & 1,8462 \\
IX & 1,1893 \\
X & 1,7062 \\
\hline Rata-rata $(\mathrm{X})$ & $1,6462 \sim 1,6$ \\
\hline
\end{tabular}

Perhitungan penambahan ekstrak: $\mathrm{A}=\frac{\mathrm{B}}{\mathrm{C} \times \mathrm{D}}$

Keterangan $\mathrm{B}=$ Rata-rata individu dalam mengambil pasta gigi

$\mathrm{C}=$ Jumlah sediaan yang akan dibuat

$\mathrm{D}=$ Konsentrasi ekstrak ( 25, 50 dan $100 \mathrm{mg} / \mathrm{mL})$

Tabel 3. Nilai rata-rata diameter zona bunuh ekstrak etanol O. Basilicum terhadap pertumbuhan bakteri $S$. mutans

\begin{tabular}{cc}
\hline Konsentrasi $(\mathrm{mg} / \mathrm{mL})$ & Rerata zona bunuh $(\mathrm{mm})$ \\
\hline 25 & 3,594 \\
50 & 4,194 \\
100 & 6,050 \\
150 & 6,247 \\
200 & 5,885 \\
Kontrol (-) & - \\
\hline
\end{tabular}

\section{HASIL DAN PEMBAHASAN}

\section{Pengujian aktivitas antibakteriesktrak daun kemangi (Ocimum basilicum L.)}

Hasil pengujian aktivitas antibakteri ekstrak etanol $O$. Basilicum terhadap bakteri $S$. mutans menunjukkan adanya zona bunuh. Uji ini dilakukan terhadap beberapa perlakukan konsetrasi ekstrak $O$. Basilicumyaitu $25 \mathrm{mg} / \mathrm{mL}, 50$ $\mathrm{mg} / \mathrm{mL}, 100 \mathrm{mg} / \mathrm{mL}, 150 \mathrm{mg} / \mathrm{mL}, 200$ $\mathrm{mg} / \mathrm{mL}$ dan kontrol negatif (-).

Menurut Davis dan Stout (1971) dalam Rabbani [9]kriteria kekuatan daya antibakteri sebagai berikut,diameter zona hambat $5 \mathrm{~mm}$ atau kurang dikategorikan lemah, diameter zona hambat 5-10 mm dikategorikan sedang, diameter zona hambat 10-20 mm dikategorikan kuat dan zona hambat $20 \mathrm{~mm}$ atau lebih dikategorikan sangat kuat. Dari pernyataan tersebut ekstrak etanol daun kemangi pada konsetrasi $25 \mathrm{mg} / \mathrm{mL}, 50$ $\mathrm{mg} / \mathrm{mLdan} 200 \mathrm{mg} / \mathrm{mL}$ termasuk dalam kategori lemah. Sedangkan pada konsentrasi $100 \mathrm{mg} / \mathrm{mL}$ dan $150 \mathrm{mg} / \mathrm{mL}$ termasuk dalam kategori sedang.

Hasil pengujian menunjukkan penghambatan ekstrak terhadap bakteri 
uji mengalami peningkatan dari konsentrasi $25 \mathrm{mg} / \mathrm{mL}$ sampai pada konsentrasi $150 \mathrm{mg} / \mathrm{mL}$. Penghambatan ekstrak mengalami penurunan pada konsentrasi $200 \mathrm{mg} / \mathrm{mL}$ disebabkan oleh viskositas dari ekstrak mengalami peningkatan dengan semakin meningkatnya konsentrasi dari ekstrak. Peningkatan viskositas ini menyebabkan penurunan laju difusi dari paper disksehingga kemampuan difusi ekstrak ke medium juga akan dipengaruhi. Sehingga semakin pekat ekstrak maka semakin kecil zona penghambatan yang terbentuk. Hal ini diungkapkan oleh Cappucino (1978) dalam Zaraswati [10] besar kecilnya daerah hambatan dipengaruhi oleh laju pertumbuhan mikroorganisme, kemampuan dan laju difusi bahan aktif pada medium, kepekaan mikroorganisme terhadap zat aktif serta ketebalan dan viskositas medium.

Aktivitas penghambatan S.mutansoleh ekstrak etanol daun kemangi dipengaruhi oleh adanya pengaruh senyawa metabolit sekunder yang terdapat dalam ekstrak tersebut. Hasil pengujian fitokimia pada daun kemangi yang dilakukan oleh Maria [7] ekstrak etanol daun kemangi menunjukkan hasil positif pada golongan senyawa tanin, flavanoid dan minyak atsiri.

Senyawa flavanoid berperan sebagai antibakteri dengan cara merusak membran sel bakteri pada bagian fosfolipid sehingga mengurangi permeabilitas yang mengakibatkan bakteri mengalami kerusakan [7]. Menurut Dewi dalam Rabbani [9]. Struktur dinding sel bakteri juga menentukan penetrasi, ikatan dan aktivitassenyawa antibakteri. Bakteri S.mutans merupakan bakteri gram positif yang memilikistruktur dinding sel dengan lebih banyakpeptidoglikan, sedikit lipid dan mengandungpolisakarida (asam teikoat). Asam teikoatmerupakan polimer yang larut dalam air, yang berfungsi sebagai transport ion positif untuk keluar atau masuk. Sifat larut air inilah yang menunjukkan bahwa dinding sel bakteri gram positif bersifat lebih polar [7]. Sedangkan menurut Makkar (1993) dalam Maria [7] senyawa tanin berperan sebagai antibakteri karena memiliki kemampuan membentuksenyawa kompleks dengan protein melalui ikatan hidrogen, jika terbentuk ikatan hidrogen antara tanin dengan protein maka protein akan terdenaturasi sehingga metabolisme bakter menjadi terganggu. Robinson mengatakan dalam Maria [7] minyak atsiri merupakan minyak yang mudah menguap, minyak atsiri umumnya dibagi menjadi dua komponen yaitu golongan hidrokarbon dan golongan hidrokarbon teroksigenasi. Senyawa-senyawa turunan hidrokarbon teroksigenasi (fenol) memiliki daya antibakteri yang kuat.

Konsentrasi $25 \mathrm{mg} / \mathrm{mL} ， 50$ $\mathrm{mg} / \mathrm{mL}$ dan $100 \mathrm{mg} / \mathrm{mL}$ merupakan konsentrasi terpilih yang ditambahkan dalam sediaan kerena pada uji pendahuluan Formula 1 dengan penambahan ekstrak 25-150 $\mathrm{mg} / \mathrm{mL}$, ketiga konsentrasi tersebut menunjukkan hasil penghambatan yang baik terhadap bakteri S.mutans.

\section{Pengujian aktivitas antibakteri pasta gigi ekstrak daun kemangi (Ocimum basilicum L.)}

Hasil pengujian basis pasta gigi menunjukkan zona penghambatan terhadap bakteri S.mutans dapat dilihat pada Gambar 1.

Hasil pengujian sediaan pasta gigi ekstrak daun kemangi menunjukkan zona penghambatan terhadap bakteri S.mutans dapat dilihat pada Gambar 2. 


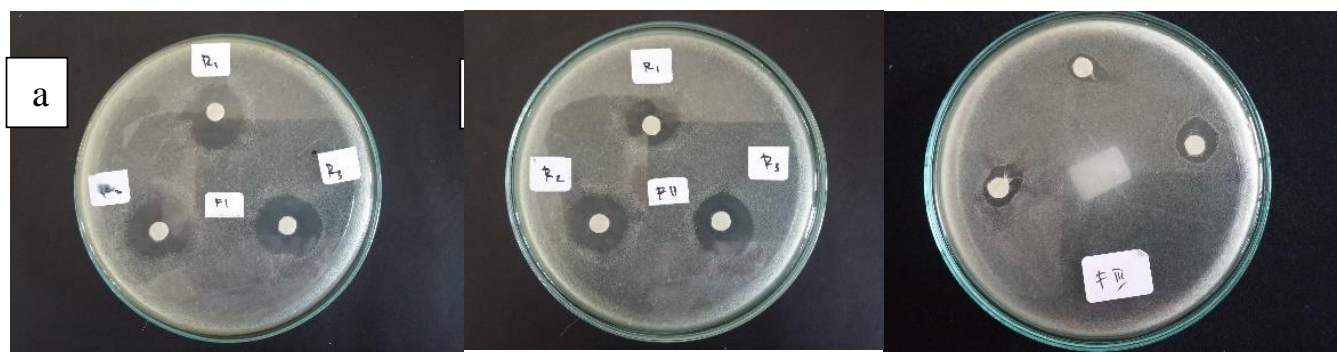

Gambar 1. Uji antibakteri basis pasta gigi terhadap bakteri Streptococcus mutans

Keterangan:

(a) F1 (Kalsium karbonat 37\%) replikasi I, II dan III

(b) F2 (Kalsium karbonat $42 \%$ )replikasi I, II dan III

(c) F3 (Kalsium karbonat $47 \%$ ) replikasi I, II dan III
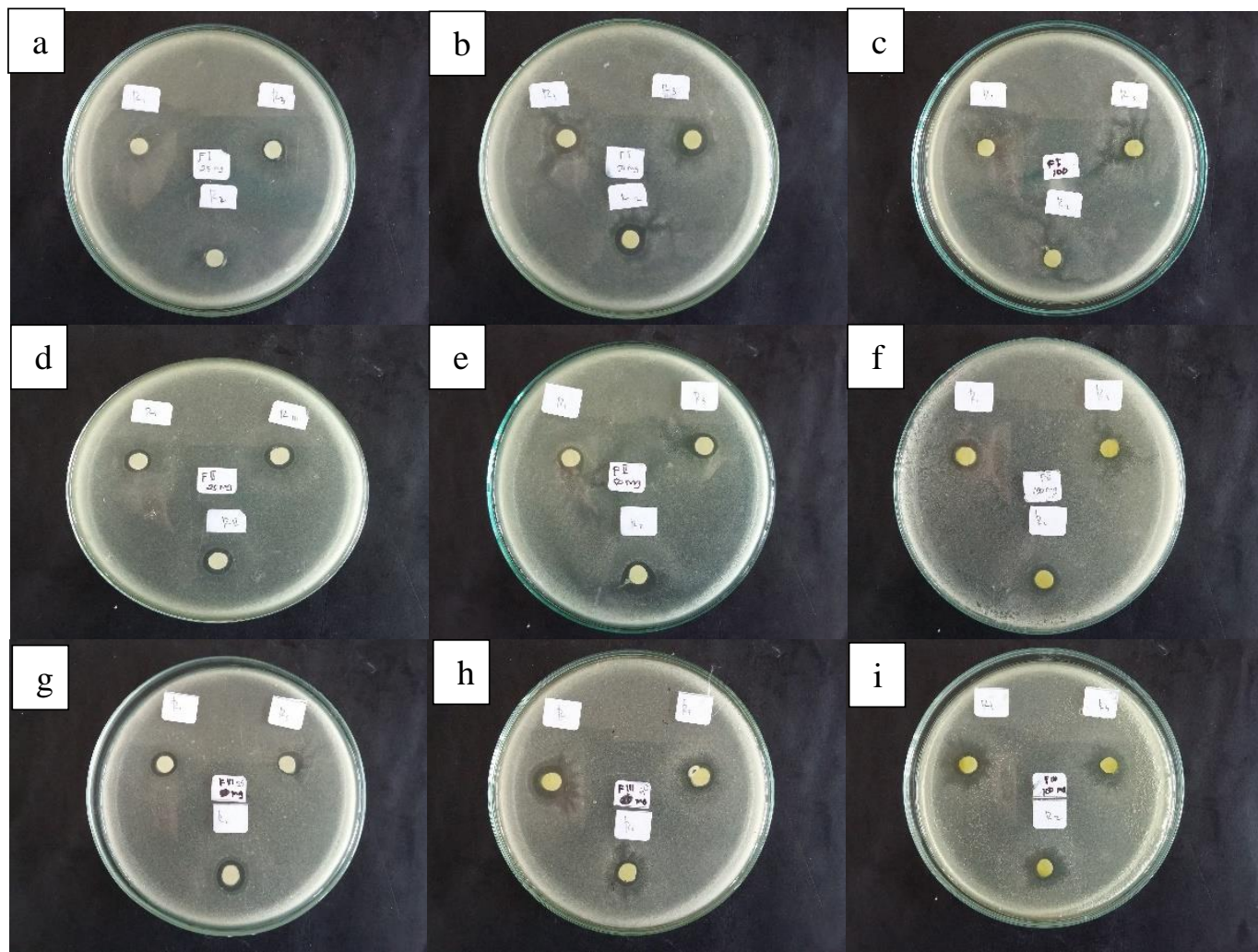

Gambar 2. Uji antibakteri sediaan pasta gigi ekstrak daun kemangi terhadap bakteri Streptococcus mutans

Keterangan:

F1 (Kalsium karbonat 37\%) replikasi I, II dan III dengan konsentrasi eksrak (a) 25 mg, (b) $50 \mathrm{mg}$, (c) $100 \mathrm{mg}$

FII (Kalsium karbonat 42\%) replikasi I, II dan III dengan konsentrasi eksrak (d) $25 \mathrm{mg}$, (e) $50 \mathrm{mg}$, (f) $100 \mathrm{mg}$

F1II (Kalsium karbonat 47\%) replikasi I, II dan III dengan konsentrasi eksrak (g) $25 \mathrm{mg}$, (h) $50 \mathrm{mg}$, (i) $100 \mathrm{mg}$

Gambar 1 menunjukkan bahwa larutan uji basis pasta gigi memiliki aktivitas antibakteri terhadap bakteri Streptococcus mutans yang ditandai dengan adanya zona bunuh disekitar paper disk. Pada gambar 1 menunjukkan adanya perbedaan aktivitas antibakteri dari masing-masing basis pasta gigi 
dimana F1 menunjukkan zona bunuh yang paling baik dibandingkan dengan F2 dan F3.
Data yang menunjukkan zona bunuh dan zona hambat yang terbentuk dari hasil aktivitas antibakteri pasta gigi terhadap bakteri uji dapat terlihat pada Tabel 4 dan Tabel 5.

Tabel 4. Rerata diameter zona bunuh basis pasta gigi

\begin{tabular}{cc}
\hline Formula & Rerata zona bunuh $(\mathrm{mm})$ \\
\hline F1 ( Kalsium karbonat 37 \%) & 11,386 \\
F2 ( Kalsium karbonat 42 \%) & 10,542 \\
F3 ( Kalsium karbonat 47 \%) & 5,084 \\
\hline
\end{tabular}

Tabel 5. Rerata diameter zona hambat pasta gigi ekstrak daun kemangi (Ocimum basilicum $\mathrm{L}$ )

\begin{tabular}{ccc}
\hline Formula & Kosentrasi ekstrak $(\mathrm{mg})$ & Rerata zona hambat $(\mathrm{mm})$ \\
\hline F1 & 25 & 1,864 \\
& 50 & 4,103 \\
& 100 & 1,241 \\
F2 & 25 & 3,352 \\
& 50 & 2,858 \\
& 100 & 4,028 \\
F3 & 25 & 2,650 \\
& 50 & 3,033 \\
& 100 & 3,263 \\
\hline
\end{tabular}

Tabel 3 menunjukkan bahwa aktivitas antibakteri basis pasta gigi pada F3 termasuk dalam kategori sedang dengan nilai zona bunuh antara 5-10 mm. Sedangkan untuk F1 dan F2 termasuk dalam kategori kuat dengan nilai zona bunuh 10-20 mm. Perbedaan diameter zona bunuh dapat dipengaruhi oleh kemampuan difusi paper diskterhadap basis pasta gigi, yang mana pada basis pasta memvariasikan konsentrasi dari kalsium karbonat sebagai abrasif. Adanya abrasif pada pasta gigi berperan sebagai agen pengosok. Abrasif pada pasta gigi biasanya digunakan pada kisaran 30-50 $\%$. Penggunaan abrasif diberbagai konsentrasi ini akan menghasilkan perbedaan viskositas dan memungkinkan mempengaruhi dari efektifitas pasta gigi dalam menghasilkan zona penghambatan terhadap bakteri uji. Basis pasta gigi menunjukkan aktivitas antibakteri dimungkinkan oleh adanya kandungan natrium lauril sulfat dan mentol yang terdapat pada pasta gigi [8].

Tabel 4 menujukkan bahwa aktivitas antibakteri pasta gigi ekstrak daun kemangi pada semua formula menunjukkan kategori lemah berdasarkan hasil dari rerata zona hambat sediaan $\leq 5$ $\mathrm{mm}$. Pasta gigi $\mathrm{F} 1$ dengan penambahan konsentrasi ekstrak kemangi $50 \mathrm{mg}$ menujukkan aktifitas terbaik dalam menghasilkan zona penghambatan $(4,103$ $\mathrm{mm})$. Hal ini berkorelasi dengan hasil pengujian basis pasta gigi di mana F1 $(11,386 \mathrm{~mm})$ menunjukkan zona penghambatan yang baik diantara formula lainnya. Jika ditinjau dari hasil zona penghambatan terjadi penurunan diameter zona yang dihasilkan sebelum dan sesudah ditambahkan ekstrak. Hal ini 
terjadi dimungkinkan karena adanya interaksi antara ekstrak dan basis pasta. Penurunan zona ini dibutuhkan melihat zona pada basis pasta menghasilkan efek antibakteri yang kuat. Sedangkan bakteri yang terdapat dimulut merupakan bakteri flora normal sehingga keberadaannya masih dibutuhkan didalam mulut. Hal ini didukung oleh penelitian Rini [10] yang melakukan penelitian perbedaan daya hambat pasta gigi herbal terhadap $S$. mutans. Hasil rerata zona hambat yang dihasilkan oleh setiap pasta gigi yaitu antara 19,79-25,48 dengan jumlah (N) adalah 10 .

\section{KESIMPULAN}

Hasil penelitian yang dilakukan menyimpulkan bahwa pasta gigi ekstrak daun kemangi yang mengandung abrasif di berbagai konsentrasi $(37,42$, dan 47 $\%$ ) menghasilkan zona penghambatan terhadap pertumbuhan bakteri $S$. mutans dengan diameter penghambatan 1, 2414,028 mm. Hasil ini mendukung potensi tanaman di Indonesia sebagai produk alami dalam mencegah masalah gigi dan mulut. Penelitian lebih lanjut yang diperlukan adalah melakukan pengujian stabilitas fisika sediaan pasta gigi.

\section{DAFTAR PUSTAKA}

1. Ambarwati FE, Utami DF dan Pramono D.2012. Pengaruh pemberian larutan ekstrak jeruk nipis(Citrus aurantifolia) terhadap pembentukan plak gigi. Jurnal Media Medika Muda.

2. Badan Penelitian dan Pengembangan Kesehatan. 2007. Riset Kesehatan Dasar $\quad$ (RISKESDAS) 2007. Departemen Kesehatan RI : Jakarta.

3. Rizki, Y.R., Priyawan, R., Widodo. 2014. Perbandingan Efektivitas Pasta Gigi Herbal Dengan Pasta Gigi Non Herbal Terhadap Penurunan Indeks
Plak Pada Siswa Sdn Angsau 4 Pelaihari. JurnalKedokteran Gigi Vol II. No 2.

4. Harris, 1987, Flurosis Therapy Primary Preventive Dentistry, 2nd ed. Appleton \& Large, Norwalk, Connnenticut, Los Angeles, California.

5. Maria, A., Masnur, T., Siti, K. 2015. Uji Aktivitas Antibakteri Ekstrak Etanol Daun Kemangi (Ocimum sanctum L.) Terhadap Pertumbuhan Bakteri Escherichia coli dan Staphylococcus aureus. Jurnal Protobionat Vol. 4 No 1.

6. Ardiana, D. Y., Martha, P., Teuku, N., Puji, A. 2013. Formulasi Mouthwash Minyak Atsiri Daun Kemangi (OcimumbasilicumL.) Serta Uji Antibakteri Dan Antibiofilm Terhadap Bakteri Streptococcus mutans Secara In Vitro. Traditional Medicine Journal, Vol 18 No 2.

7. Henny, L., Rustini, Dian, S., Dachriyanus. 2010. Formulation Of Anti-Plaque Toothpaste From Standardized Gambir Extract And Its Antimicrobial Activity. Jurnal Farmasi Indonesia Vol. 5 No. 2

8. Rabbani, H. J., Achmad, G., Tantin, E. 2014. Daya Antibakteri Ekstrak Kulit Apel Manalagi (Malussylvestris Mill.) Terhadap Pertumbuhan Streptococcus mutans. e-Jurnal Pustaka Kesehatan, Vol. 2 No.1.

9. Zaraswati, D dan Eva, J. 2011. Uji Efektivitas Ekstrak Kasar Alga Merah (EucheumaCottonii) Sebagai Antibakteri Terhadap Bakteri Patogen. Artikel publikasi.

10. Rini, P. 2005. Perbedaan daya hambat terhadap Streptococcus mutans dari beberapa pasta gigi yang mengandung herbal. Majalah Kedokteran Gigi (Dent.J) Vol. 38, No 2. 